\title{
A SIMPLE PROOF OF OPPENHEIM'S DOUBLE INEQUALITY RELATING TO THE COSINE AND SINE FUNCTIONS
}

\author{
FEng QI, QIU-Ming LUO AND BAI-Ni GuO
}

Abstract. In the paper, the authors provide a simple proof of Oppenheim's double inequality relating to the cosine and sine functions. In passing, the authors survey this topic.

Mathematics subject classification (2010): Primary 33B10; secondary 26D05.

Keywords and phrases: Simple proof, Oppenheim's double inequality, cosine function, sine function, monotonicity.

\section{REFERENCES}

[1] G. D. Anderson, M. K. VAmanamurthy, And M. Vuorinen, Inequalities for quasiconformal mappings in space, Pacific J. Math. 160 (1993), no. 1, 1-18.

[2] Á. BARICZ AND L. ZhU, Extension of Oppenheim's problem to Bessel functions, J. Inequal. Appl. 2007 (2007), Article ID 82038, 7 pages; Available onine at http://dx.doi.org/10.1155/2007/82038.

[3] W. B. CARVER, Extreme parameters in an inequality, Amer. Math. Monthly 65 (1958), no. 2, 206209.

[4] C.-P. Chen, W.-S. Cheung, And W. WAng, On Shafer and Carlson inequalities, J. Inequal. Appl. 2011 (2011), Article ID 840206, 10 pages;

Available online at http://dx.doi.org/10.1155/2011/840206.

[5] G. T. F. DE ABREU, Arbitrarily tight upper and lower bounds on the Gaussian q-function and related functions, 2009 IEEE International Conference on Communications (ICC 2009), Vols 1-8, 1944-1949, Dresden, Germany, June 14-18, 2009;

Available online at http://dx.doi.org/10.1109/ICC.2009.5198762.

[6] A. M. FinK, Two inequalities, Univ. Beograd. Publ. Elektrotehn. Fak. Ser. Mat. 6 (1995), 48-49.

[7] B.-N. Guo AND F. QI, Sharpening and generalizations of Carlson's inequality for the arc cosine function, Hacet. J. Math. Stat. 39 (2010), no. 3, 403-409.

[8] B.-N. GUO AND F. QI, Sharpening and generalizations of Shafer-Fink's double inequality for the arc sine function, Filomat 27 (2013), in press; Available online at http://arxiv.org/abs/0902.3036.

[9] Z.-H. HUO, D.-W. NIU, J. CAO, AND F. QI, A generalization of Jordan's inequality and an application, Hacet. J. Math. Stat. 40 (2011), no. 1, 53-61.

[10] B. J. MALEŠEviĆ, An application of $\lambda$-method on Shafer-Fink's inequality, Univ. Beograd. Publ. Elektrotehn. Fak. Ser. Mat. 8 (1997), 90-92.

[11] D. S. Mitrinović, Analytic Inequalities, Springer-Verlag, 1970.

[12] D.-W. NIU, J. CAO, AND F. QI, Generalizations of Jordan's inequality and concerned relations, Politehn. Univ. Bucharest Sci. Bull. Ser. A, Appl. Math. Phys. 72 (2010), no. 3, 85-98.

[13] D.-W. NiU, Z.-H. HUO, J. CAO, AND F. QI, A general refinement of Jordan's inequality and a refinement of L. Yang's inequality, Integral Transforms Spec. Funct. 19 (2008), no. 3, 157-164; Available online at http://dx.doi.org/10.1080/10652460701635886.

[14] A. Oppenheim, E1277, Amer. Math. Monthly 64 (1957), no. 6, 504.

[15] W.-H. PAN AND L. ZHU, Generalizations of Shafer-Fink-type inequalities for the arc sine function, J. Inequal. Appl. 2009 (2009), Article ID 705317, 6 pages;

Available online at http://dx.doi.org/10.1155/2009/705317. 
[16] I. Pinelis, L'Hôspital type rules for monotonicity, with applications, J. Inequal. Pure Appl. Math. 3 (2002), no. 1, Art. 5;

Available online at http://www.emis.de/journals/JIPAM/article158.html.

[17] F. QI, L.-H. CUI, AND S.-L. XU, Some inequalities constructed by Tchebysheff's integral inequality, Math. Inequal. Appl. 2 (1999), no. 4, 517-528;

Available online at http://dx.doi.org/10.7153/mia-02-42.

[18] F. QI AND B.-N. GUO, A concise proof of Oppenheim's double inequality relating to the cosine and sine functions, Available online at http://arxiv.org/abs/0902.2511.

[19] F. QI AND B.-N. GUO, Sharpening and generalizations of Shafer's inequality for the arc sine function, Integral Transforms Spec. Funct. 23 (2012), no. 2, 129-134;

Available online at http://dx.doi.org/10.1080/10652469.2011.564578.

[20] F. QI AND Q.-D. HAO, Refinements and sharpenings of Jordan's and Kober's inequality, Mathematics and Informatics Quarterly 8 (1998), no. 3, 116-120.

[21] F. QI, D.-W. NIU, AND B.-N. GuO, Refinements, generalizations, and applications of Jordan's inequality and related problems, J. Inequal. Appl. 2009 (2009), Article ID 271923, 52 pages; Available online at http://dx.doi.org/10.1155/2009/271923.

[22] F. QI, S.-Q. ZHANG, AND B.-N. GUO, Sharpening and generalizations of Shafer's inequality for the arc tangent function, J. Inequal. Appl. 2009 (2009), Article ID 930294, 9 pages; Available online at http://dx.doi.org/10.1155/2009/930294.

[23] J. SÁNDOR, On some trigonometric inequalities, Erdelyi Mat. Lapok, 3 (2002), no. 2, 13-14.

[24] J. SÁNDOR AND M. BEnCZE, On Huygens's trigonometric inequality, RGMIA Res. Rep. Coll. 8 (2005), no. 3, Art. 14; Available online at http://rgmia.org/v8n3.php.

[25] S.-Q. ZhANG AND B.-N. GuO, Monotonicity results and inequalities for the inverse hyperbolic sine, Chinese Quart. J. Math. 24 (2009), no. 3, 394-388.

[26] J.-L. ZhaO, C.-F. WeI, B.-N. GUo, AND F. QI, Sharpening and generalizations of Carlson's double inequality for the arc cosine function, Hacet. J. Math. Stat. 41 (2012), in press.

[27] L. ZHU, A solution of a problem of Oppeheim, Math. Inequal. Appl. 10 (2007), no. 1, 57-61.

[28] L. ZHU, New inequalities of Shafer-Fink type for arc-hyperbolic sine, J. Inequal. Appl. 2008 (2008), Article ID 368275, 5 pages; Available online at http://dx.doi.org/10.1155/2008/368275. 